\title{
Influence of Motivation on the Performance of Government Employees
}

\author{
Arifuddin Usman \\ Faculty of Sport Science \\ Universitas Negeri Makassar \\ Makassar, South Sulawesi, Indonesia
}

\author{
Herman \\ Faculty of Sport Science \\ Universitas Negeri Makassar \\ Makassar, South Sulawesi, Indonesia \\ hermanfikunm@yahoo.co.id
}

\begin{abstract}
The purpose of this research was to find out the influence of motivation on employee performance Youth and Sports Department of South Sulawesi province. This research is descriptive research. The population is all employees of Youth and Sports Department of South Sulawesi. Data analysis technique used in this research is descriptive analysis and frequency, regression analysis. The results of data analysis can be concluded that: (1) Motivation has a significant influence on the employees' performance. It happened because the application of motivation and perceived stimulus has been very good for the employee. (2) Simultaneously, motivation has a positive effect on the performance of staff. This is due to the motivation has a very strong relationship to employee performance. (3) The motivation on government employee performance has a very strong interpretation. While the determination coefficient or $\mathbf{R}$ Square showed the value on the interpretation has strong influence.
\end{abstract}

\section{Keywords: motivation; employee; performance}

\section{INTRODUCTION}

In the current era of reform bureaucratic system that applied is similar to when the new order is still in power, for example, centralized system of government by the central government which always strives in all aspects. Toward considerations of development effectiveness, the central government controls all the activities in each province and the city. Local Government only does what has been established and directives given by the Central Government.

Youth and Sports Department of South Sulawesi Province as the center and the activities of the government administration in the field of sport must be supported by human resources that are reliable in their field and able to create a work culture that is conducive for any personnel can translate well what should be done in achieving organizational goals, Resources Youth and Sports of South Sulawesi Quality, Top and Competitive Global

An indicators success of a leader is the success of its employees in completing their tasks and carrying out their responsibilities. It is unseparated with the motivation that already granted to them. Most certainly motivate is to work more productively in their initiate, but not apart from leadership. While the leader who succeeded in giving examples will create an environment that drives employee behavior to a destination that can provide fulfillment [1]. To create a culture of work about improving the performance of employees in the Department of Youth and Sport of South Sulawesi figure certainly need leaders who can see and understand leadership styles that can be applied to staff by the circumstances at hand [2].

Quality programs that have been developed over the years, a have still many complaints by various parties both youth issues and problems of sports, including sports achievements. Government employees must be reliable in their field and able to create a work culture that is conducive for any personnel can translate well what they should be done in achieving organizational goals.

Personal assessment of performance against the organization as a whole is something that must be done to find out how much they have achieved and how the needs of organizations with interested parties outside the organization, either directly or indirectly. Through performance assessment organization will be able to know whether the organization in own personal performance as expected or still needs help and outsiders while fixing or improving personal performance within the organization, so that what is wanted can be gotten [3].

Mangkunegara and Prabu stated that the motivation is formed from the attitude of an employee in the face of the work situation [4]. Motivation is a condition that drives selfdirected employees to achieve organizational goals. While Nawawi stated, motivation is essentially the motive, which means a boost, for someone to do something [5]. Thus the motivation means that may encourage or make someone do something because actions / activities that take place consciously.

According to Maslow et al. motivation have five levels namely: physiological (physiologist), safety (security), social (social relationships), esteem (awards), and self-actualization (self-actualization), and achieved in stages [6]. The desired needs someone tiered, meaning the first requirement is met, then the need for a second level will be the main one. Furthermore, if the second level requirements are met, there appears a need for the third and so on until the fifth level of needs. The basic theory is: a) humans are willing, he always wants more. The desire is continuous and only stops when the end of life comes, b) a requirement has been satisfied is 
not a motivator for the culprit, only the unmet needs that will be a motivator, c) the needs of the human family in one level.

\section{METHODOLOGY}

There are two main types of variables in this research is the dependent variable and the independent variables. The dependent variable is an employee performance, while the independent variable is the motivation of government employee.

The data collect used interview techniques by using question or informant using interview guide. It also used observation by observing the data in the Department of Youth and Sports of South Sulawesi Province. Moreover, the last technique is documentation which recording data directly from documents related to the study.

Measurement of study variables used Likert Scale that measures the attitudes, opinions, and perceptions of a person or a group of the social phenomenon through data collection methods using questionnaires distributed directly to the respondents to the employees of the office of Youth and Sports of South Sulawesi province. With Likert scale, measured variables are translated into indicators are used as a starting point to construct items instruments which can be a statement. Answer each item of instrument that uses a Likert scale has gradations from very positive to negative.

\section{RESULT AND DISCUSSION}

The result of the research is described in the descriptive and inferential analysis.

A Result

TABLE 1. DESCRIPTIVE ANALYSIS

\begin{tabular}{|l|l|r|r|}
\hline \multicolumn{2}{|c|}{} & motivation & \multicolumn{2}{|c|}{$\begin{array}{c}\text { employees } \\
\text { performance }\end{array}$} \\
\hline \multirow{2}{*}{$\mathrm{N}$} & Valid & 30 & 30 \\
\cline { 2 - 4 } & Missing & 0 & 0 \\
\hline Mean & 36.1000 & 71.7000 \\
\hline Std. Deviation & 5.09462 & 8.06931 \\
\hline Range & 19.00 & 34.00 \\
\hline Minimum & 26.00 & 51.00 \\
\hline Maximum & 45.00 & 85.00 \\
\hline Sum & 1083.00 & 2151.00 \\
\hline
\end{tabular}

From the results table above can be concluded as follows:

1. Percentage of Motivation

Based on the results of motivational data percentage of $30(100 \%)$ people, who have very good categories is 11 people $(36.7 \%)$, in good category is $17(56.7 \%)$ and enough category is $2(6.7 \%)$. Thus, it can be concluded take the percentage of data categorized good motivation.

2. Percentage of Employee Performance
Based on the results the percentage of employee performance data of $30(100 \%)$ of people, who have very good categories is 16 people $(53.3 \%)$, in good category is $13(43.3 \%)$, and enough category is $1(3.3 \%)$. Thus, it can be concluded that the percentage of data categorized very good employee performance.

Based on the test results of regression analysis of data between motivation on employee performance of Youth and Sports Department of South Sulawesi province. Correlation and regression values obtained 0.888 with a probability level of $(0.000)<\alpha 0,05$, to the value of $\mathrm{R}$ Square (coefficient of determination), is 0.789 . It means that motivation explains $78.9 \%$ of employee performance. From the ANOVA test or $\mathrm{F}$ test, obtained $\mathrm{F}$ count was 104.633 with a significance level of 0.000 . Therefore the probability $(0.000)$ is much smaller than $<\alpha 0,05$, the regression model can be used to predict the performance of an employee (can be applied to a population where the sample was taken). A t-test was obtained 10.229 with a significance level of 0.000 . Therefore the probability $(0.000)$ is much smaller than $<\alpha 0,05$. So Ho refused, and $\mathrm{H} 1$ accepted or significant regression coefficient, or the motivation to influence the results of employee performance significantly.

\section{B Discussion}

Based on the findings, the motivation influences the results of government employee performance significantly. It is related to the finding by Alonso and Lewis that agencies based promotion and pay decisions on performance were positively related to performance (as measured by grades and ratings), even after correcting for reciprocal causation [7].

According to Timpe, states that labor standards are: Standard work is considered satisfactory if the statement indicates some key areas of responsibility of 15 employees, includes an activity how work gets done, and to bring attention to the mechanisms of how the quantitative results performance is measured [8]. According Lestari and Yunianto performance standards are the targets, goals, objectives efforts of employees within a certain time. In carrying out its work, the employee must direct all the energy, thoughts, skills, knowledge, and their work time to achieve what is specified by the standards of performance [9]. According to Schuler and Jackson there are three basic types of performance criteria", namely: a) criteria based on the nature (focusing on the personal characteristics of an employee). b) criteria based on behavior (criteria that are important for jobs that require inter-personal relationships). c) criteria based on the results (criteria that focus on what you have achieved or generated) [10].

Dessler and Tan argue about the performance of employees are the actual achievements of employees compared with the achievements expected from employees [11]. Expected performance is an achievement standard set as a reference so the performance of employees by its position compared to the standards made.

Durant et al. stated that to change human performance by intervening will always be an uncertain and indeterminate 
process [12]. The increasing diversity of organizational and structural forms will bring a variety of motivational tools. It is long identified with the private sector in playing transformed public sector. Thus, the group financial incentives and the understanding of the contextual factors influence participation and other forms of intervention. Finally, professionals in public organizations can contribute significantly to the expansion of the knowledge about performance in public organizations.

Ritz have been concluding that there is an important link between managerial techniques and the individual perception in administrative practice of organizational performance [13]. Then, to be effective, practitioners need to integrate special management tools into the public sector. There are needs a consideration of the employee's commitment to the public interest to fulfill the specific requirements.

\section{CONCLUSION}

Based on the data above, we can conclude that motivation has a significant influence on the performance of employees at the office of Youth and Sports Provincial South Sulawesi. It caused of motivation, and perceived stimulus has been a very good employee. Moreover, simultaneously motivation has positive significant effect on the performance of staff. Due to the motivation have a very strong relationship to employee performance. Moreover, third, the motivation on employee performance has a very strong interpretation. While the coefficient of determination or $\mathrm{R}$ Square showed the value on the interpretation of this has a strong influence.

\section{REFERENCE}

[1] G. Chen, B. L. Kirkman, R. Kanfer, D. Allen, and B. Rosen, 'A multilevel study of leadership, empowerment, and performance in teams.', J. Appl. Psychol., vol. 92, no. 2, p. 331, 2007.

[2] K. W. Thomas and B. A. Velthouse, 'Cognitive elements of empowerment: An "interpretive" model of intrinsic task motivation', Acad. Manag. Rev., vol. 15, no. 4, pp. 666-681, 1990.

[3] J. Berthel and F. G. Becker, 'Personal-Management', Grundzüge für Konzeptionen betrieblicher Pers., vol. 7, 2003.

[4] A. P. Mangkunegara and A. Prabu, 'Evaluasi kinerja sumber daya manusia', Bandung: Aditama, 2005.

[5] H. Nawawi, 'Manajemen Sumber Daya Manusia. Yogyakarta'. Gaja Mada University Press, 1998.

[6] A. H. Maslow, D. C. Stephens, G. Heil, and W. Bennis, Maslow on management. John Wiley New York, 1998.

[7] P. Alonso and G. B. Lewis, 'Public service motivation and job performance: Evidence from the federal sector', Am. Rev. Public Adm., vol. 31, no. 4, pp. 363-380, 2001.

[8] A. D. Timpe, 'Seri Manajemen Sumber Daya Manusia Kinerja', PT Gramedia, Jakarta, 1999.

[9] L. Lestari and A. Yunianto, 'THE EFFECT OF EMPOWERMENT ON EMPLOYEE PERFORMANCE WITH ORGANIZATIONAL COMMITMENT AS MEDIATING VARIABLE AND ORGANIZATIONAL CULTURE AS MODERATION VARIABLE', in Conference In Business, Accounting, And Management (CBAM), 2015, vol. 2, no. 1, pp. 335-343.

[10] R. S. Schuler and S. E. Jackson, Strategic human resource management. John Wiley \& Sons, 2008.

[11] G. Dessler and C. H. Tan, Human resource management: An Asian perspective. Pearson Prentice Hall, 2006.

[12] R. F. Durant, R. Kramer, J. L. Perry, D. Mesch, and L. Paarlberg, 'Motivating employees in a new governance era: The performance paradigm revisited', Public Adm. Rev., vol. 66, no. 4, pp. 505-514, 2006.

[13] A. Ritz, 'Public service motivation and organizational performance in Swiss federal government', Int. Rev. Adm. Sci., vol. 75, no. 1, pp. 53 78, 2009. 